\title{
New approach to modulate retinal cellular toxic effects of high glucose using marine epa and dha
}

Mélody Dutot ${ }^{1 *}$, Violaine de la Tourrette ${ }^{1}$, Roxane Fagon ${ }^{1}$ and Patrice Rat $^{2}$

\begin{abstract}
Background: Protective effects of omega-3 fatty acids against cellular damages of high glucose were studied on retinal pigmented epithelial (RPE) cells.

Methods: Retinal epithelial cells were incubated with omega-3 marine oils rich in EPA and DHA and then with high glucose $(25 \mathrm{mM})$ for 48 hours. Cellular responses were compared to normal glucose $(5 \mathrm{mM})$ : intracellular redox status, reactive oxygen species (ROS), mitochondrial succinate deshydrogenase activity, inflammatory cytokines release and caveolin-1 expression were evaluated using microplate cytometry, ELISA and flow cytometry techniques. Fatty acids incorporation in retinal cell membranes was analysed using chromatography.
\end{abstract}

Results: Preincubation of the cells with fish oil decreased ROS overproduction, mitochondrial alterations and TNF $\alpha$ release. These protective effects could be attributed to an increase in caveolin-1 expression induced by marine oil.

Conclusion: Marine formulations rich in omega-3 fatty acids represent a promising therapeutic approach for diabetic retinopathy.

Keywords: Glucose, Inflammation, Omega-3, Oxidative stress, Caveolin-1

\section{Background}

Diabetic retinopathy is the most common diabetic eye disease and a leading cause of blindness in adults. It is estimated that in 2002, diabetic retinopathy accounted for about $5 \%$ of world blindness, representing almost 5 million blind people [1].

Sustained hyperglycemia appears to be the major contributor to the development of this multifactorial disease [2]. The hallmarks of diabetic retinopathy include blood-retinal barrier breakdown [3]. The retinal pigmented epithelial (RPE) cells constitute the outer blood-retinal barrier. Oxidative stress plays a central role in the pathogenesis of diabetic retinopathy [4-6]. In addition to oxidative stress, inflammation is implicated in diabetic retinopathy. Retinal leukostasis increases within days of developing diabetes and correlates with the increased expression of retinal intercellular adhesion molecule-1 and CD18 [7-9]. Therefore, antioxidants have been found to inhibit the development of inflammatory changes in retinas of diabetic animals [5]. Omega-3 fatty

\footnotetext{
* Correspondence: melody.dutot@yslab.fr

${ }^{1}$ Yslab, Quimper, France

Full list of author information is available at the end of the article
}

acids (mainly EPA and DHA) possess antioxidant and anti-inflammatory activities. They incorporate into retinal cell membranes $[10,11]$ and could be proposed as potential preventive therapies to diabetic patients.

The aim of this study was to modulate the side effects of high glucose using marine omega-3-rich oil on RPE cells.

\section{Methods \\ Reagents}

Omega-3-rich oil (fish YS-2636) was provided from Yslab (Quimper, France). Composition of oils is summarized in table 1. Chemicals, cell culture reagents and fluorescent dyes were purchased from Sigma Aldrich, Eurobio (Les Ulis, France) and Invitrogen (Cergy Pontoise, France), respectively.

\section{Experimental procedures Cell Culture}

A human retinal pigmented epithelial cell line (ARPE19, ATCC CRL2302) was cultured under standard conditions in DMEM containing $1 \mathrm{~g} / \mathrm{L}$ of glucose supplemented with $10 \%$ foetal calf serum, $2 \mathrm{mM} \mathrm{L}$-glutamine, 
Table 1 EPA and DHA (\%) and tocopherol $(\mathrm{mg} / \mathrm{g})$ composition of tested oil

\begin{tabular}{cc}
\hline & Fish YS-2636 \\
\hline C20:5 w3 EPA & 36 \\
\hline C22:6 w6 DHA & 26 \\
\hline Mixed Tocopherol & 3.6 \\
\hline
\end{tabular}

EPA: eicosapentenoic acid

DHA: docosahexaenoic acid

$50 \mathrm{IU} / \mathrm{ml}$ penicillin and $50 \mathrm{IU} / \mathrm{ml}$ streptomycin. The medium was changed every 2 days. Confluent cultures were removed by trypsin incubation, and then the cells were counted. They were seeded into 96 -well culture microplates at a density of 80,000 cells/well and kept at $37^{\circ} \mathrm{C}$ for 24 hours.

\section{Incubation protocols}

Whenever cells reached $80 \%$ confluency, the culture medium was removed and the cells were exposed to neat fish oil for 15 minutes. The cells were rinsed with phosphate buffer and incubated in culture medium for 24 hours [12-14]. The cells were then incubated with high glucose $(4.5 \mathrm{~g} / \mathrm{L})$ for 48 hours.

\section{Metabolic activity}

Alamar Blue assay uses resazurine, a visible blue fluorogene probe, which is reduced to a red fluorescent compound (resorufin) by cellular redox enzymes. Cells were incubated with resazurine solution $(0.1 \mathrm{mg} / \mathrm{ml})$ containing culture medium supplemented with $2.5 \%$ foetal calf serum. After a 6 -h incubation time at $37^{\circ} \mathrm{C}$ in moist atmosphere with $5 \% \mathrm{CO}_{2}$, resorufin fluorometric signal $(\lambda$ exc $=535 \mathrm{~nm}, \lambda$ em $=600 \mathrm{~nm})$ was measured using a microplate fluorometer (Safire, Tecan, France).

\section{Reactive oxygen species (ROS) production evaluation}

ROS were detected with the 2',7'-dichlorofluorescein diacetate probe. Once inside the cell, this probe is cleaved by endogenous esterases and can no longer pass out of the cell. The de-esterified product becomes the fluorescent compound 2',7'-dichlorofluorescein after oxidation by reactive oxygen species. Cells were incubated for 20 minutes with a $20 \mu \mathrm{M}$ DCFH-DA solution, fluorescence detection $(\lambda$ exc $=485 \mathrm{~nm}, \lambda$ em $=535 \mathrm{~nm})$ was undertaken with a microplate fluorometer (Safire, Tecan, France).

\section{Mitochondrial dehydrogenase activity}

The activity of mitochondrial deshydrogenase was measured using the MTT probe. The assay is based on the reduction of yellow tetrazolium salt MTT onto waterinsoluble purple formazan salt by viable cells. Cells were incubated with a MTT solution at $0.5 \mathrm{mg} / \mathrm{mL}$ for 3 hours and rinsed with phosphate buffer. Formazan salt was solubilized in DMSO and absorbance detection $(\lambda$ abs $=540 \mathrm{~nm})$ was undertaken with a microplate colorimeter (Safire, Tecan, France).

\section{Cytokines release}

The release of TNF $\alpha$ in cell supernatants was determined by ELISA. After glucose incubation, cell supernatants were harvested and stored at $-20^{\circ} \mathrm{C}$ until use for cytokines measurements. The quantity of released cytokines was measured according to the manufacturer's instructions (R\&D Systems, Lille, France).

\section{Fatty acid composition of RPE cells}

The cells were centrifuged for 5 minutes at $1000 \mathrm{~g}$. The cell pellets were suspended in $1 \mathrm{~mL}$ of $0.1 \mathrm{M}$ sucrose-10 $\mathrm{mM}$ Tris buffer $\left(\mathrm{pH} \mathrm{7.4)}\right.$ at $4^{\circ} \mathrm{C}$. They were then lysed after five freeze-thaw cycles and a cold sonication for 30 to 60 seconds. Cell membranes were isolated by several ultracentrifugations. Total lipids were extracted, and membrane fatty acids were analyzed and quantified by high-pressure liquid chromatography, as previously described [15].

\section{Immunofluorescence for caveolin-1 expression}

The culture cells were harvested with trypsin-EDTA, pelleted, washed twice in PBS, and fixed in paraformaldehyde. After permeabilization, the cells were incubated with anti-caveolin-1 antibody for 45 minutes. After wash, the cells were incubated with fluorescein isothiocyanate (FITC)-conjugated secondary antibody for 45 minutes. Flow cytometric quantitation of fluorescence was measured using C6-Flow ${ }^{\circledR}$ cytometer (Accuri, France).

\section{Data Analyses}

Data in the text and graphs are shown as fluorescence percentage of the control (data are normalized to cell number), and statistical analyses was performed using a one-way ANOVA followed by a Dunnet's test $(\alpha$ risk $=$ 0.05). Each test was performed in triplicate.

\section{Results}

\section{Cell viability: metabolic activity}

As shown in Figure 1, high glucose didn't alter the cell viability of RPE cells. Tested marine oil was safe for RPE cells.

\section{Production of ROS}

As shown in Figure 2, high glucose induced a significant overproduction of ROS in RPE cells $(+32 \%)$ compared to normal glucose. Preincubation with fish YS-2636 oil totally inhibited ROS high glucose-induced production in RPE cells, as ROS production was not significantly different from normal glucose (98\% compared to normal glucose).

\section{Mitochondrial dehydrogenase activity}

As shown in Figure 3, high glucose induced a significant decrease in mitochondrial dehydrogenase activity in RPE cells $(-10 \%)$ compared to normal glucose. Fish YS-2636 oil protected cells against high glucose-induced decrease in mitochondrial dehydrogenase activity on RPE cells. 


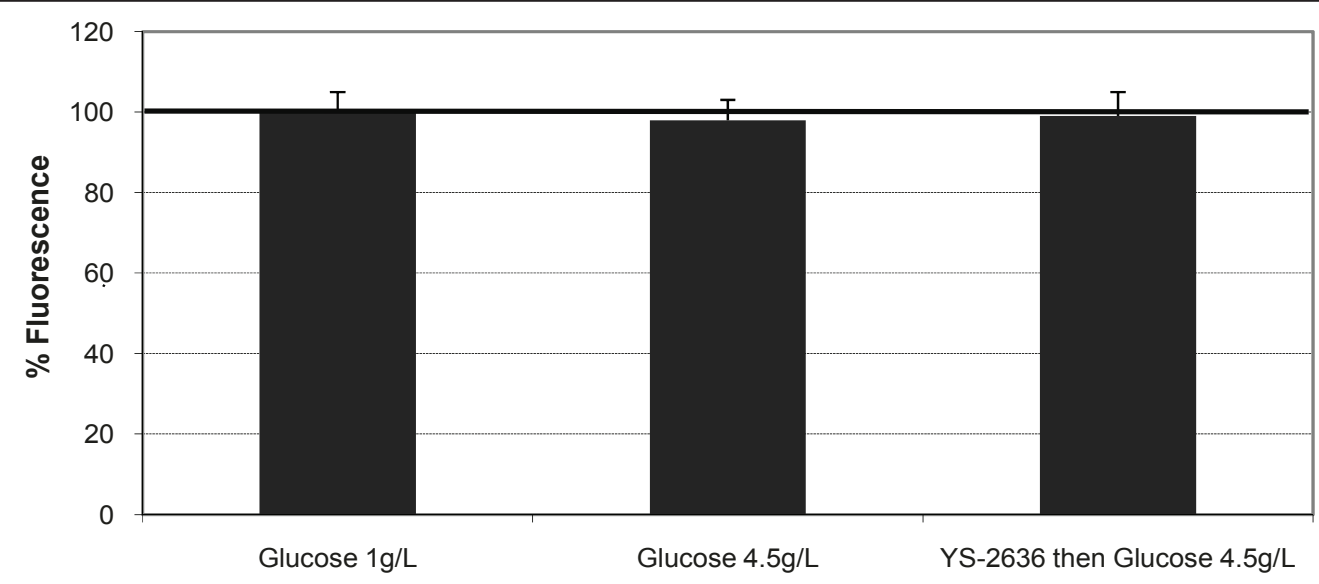

Figure 1 Metabolic activity of RPE and Müller cells. The cells were incubated with YS-2636 fish oil for 15 minutes. After the cells were rinsed with phosphate buffer, the cells were incubated with high glucose $(4.5 \mathrm{~g} / \mathrm{L})$ for 48 hours. Normal glucose $(1 \mathrm{~g} / \mathrm{L})$ was used as a cell control.

\section{Cytokines release}

As shown in Figure 4, high glucose induced TNFa release in RPE cells. YS-2636 inhibited TNF $\alpha$ release induced by high glucose.

\section{Fatty acid composition of RPE cells}

As shown in table 2 fish YS-2636 oil increased EPA (from $1.58 \%$ in control cells to $4.10 \%$ in cells incubated with YS-2636) and decreased DHA (from $11.60 \%$ in control cells to $6.65 \%$ in cells incubated with YS-2636).

\section{Caveolin-1 expression}

As shown in Figure 5, fish YS-2636 oil increased the expression of caveolin-1 in RPE cells $(+60 \%$ compared to control).

\section{Discussion}

Prolonged exposure of the cells to high glucose is shown to cause both acute and reversible changes in cellular metabolism [4]. We confirmed that high glucose induced ROS overproduction on RPE cells, in accordance with a previous study [16]. Du et al. observed that high glucose-induced oxidative stress came predominantly from mitochondria [17]. Mitochondria is the organelle where most of radicals are produced. Electron leak to oxygen through respiratory chain complexes can generate superoxide anion [18]. At the same time, the mitochondrial respiratory chain is an important target for the damaging effects of ROS [19]. In RPE cells, we observed ROS overproduction and a slight decrease in mitochondrial dehydrogenase activity. In our model (48

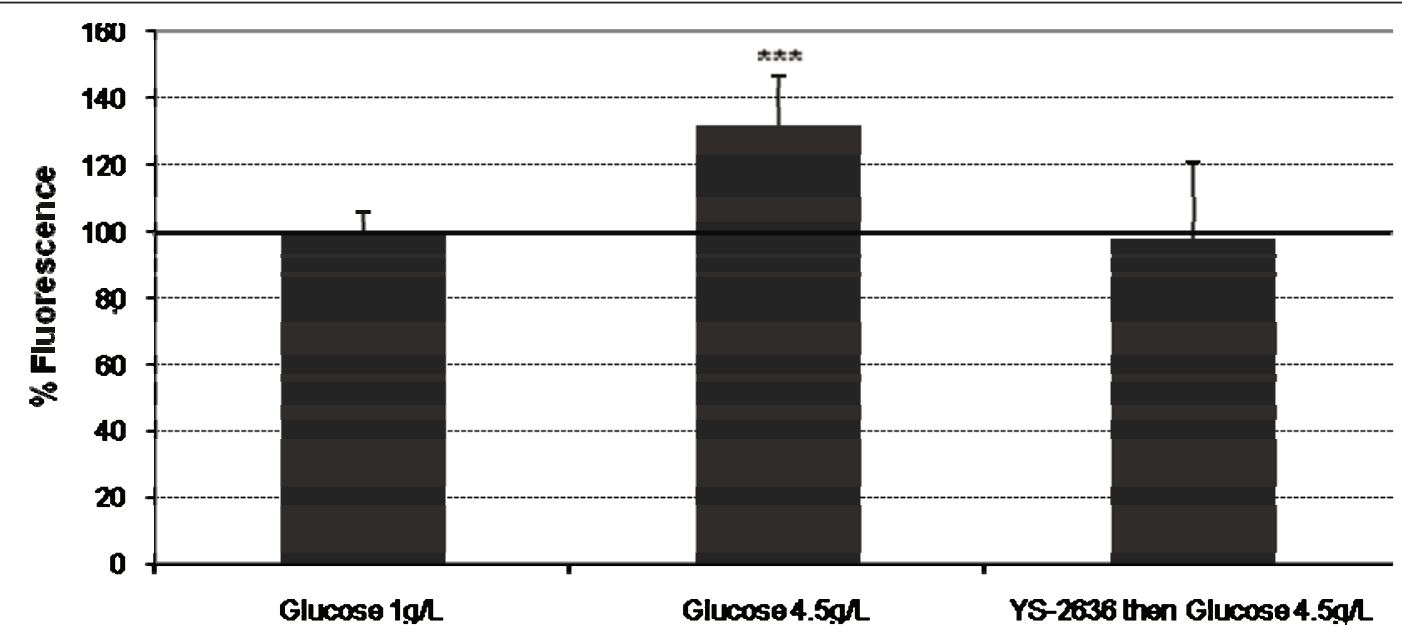

Figure 2 Production of reactive oxygen species by RPE cells and Müller cells. The cells were incubated with YS-2636 fish oil for 15 minutes. After the cells were rinsed with phosphate buffer, the cells were incubated with high glucose $(4.5 \mathrm{~g} / \mathrm{L})$ for 48 hours. Normal glucose (1 $\mathrm{g} / \mathrm{L})$ was used as a cell control. ${ }^{* * *} \mathrm{p}<0.001$. 


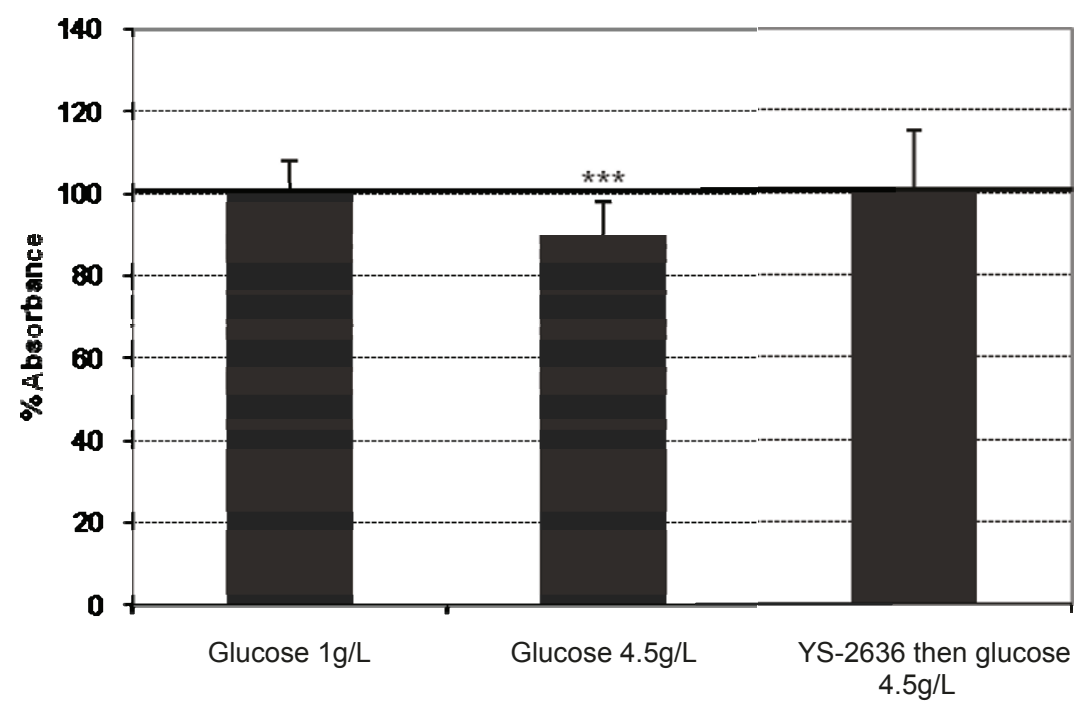

Figure 3 Mitochondrial dehydrogenase activity. The cells were incubated with YS-2636 fish oil for 15 minutes. After the cells were rinsed with phosphate buffer, the cells were incubated with high glucose $(4.5 \mathrm{~g} / \mathrm{L})$ for 48 hours. Normal glucose $(1 \mathrm{~g} / \mathrm{L})$ was used as a cell control. ${ }^{* * *} \mathrm{p}$ $<0.001$.

hours in high glucose), ROS overproduction may not be generated only by the mitochondrial respiratory chain but also through NADPH oxidase for example [20]. There is evidence that the release of TNF $\alpha$ induced by high glucose in vitro may be mediated by ROS [6]. TNF $\alpha$, overexpressed in tissues of diabetic patients $[21,22]$, has been implicated in insulin resistance. Interestingly, in our model, TNF $\alpha$ was released by RPE cells, associated with ROS overproduction.

An important role for DHA within the retina is suggested by its high levels $(8-20 \%$ of total retinal fatty acids in humans) in this tissue. Therefore, we tested the protective effects of fish oil rich in DHA (26\% of total fatty acids). This marine oil was able to prevent high glucose from being toxic to retinal cells. It also contains EPA (36\% of total fatty acids); EPA is the omega-3 homologue of arachidonic acid and competes with arachidonic acid for metabolism by COX enzymes. Arachidonic acid is at the origin of inflammatory mediators whereas EPA is at the origin of anti-inflammatory mediators. An increase in EPA can lead to a decrease in arachidonic acid [12] and then to a decrease in the inflammatory response. We observed that incubation of RPE cells with fish oil increased EPA and decreased

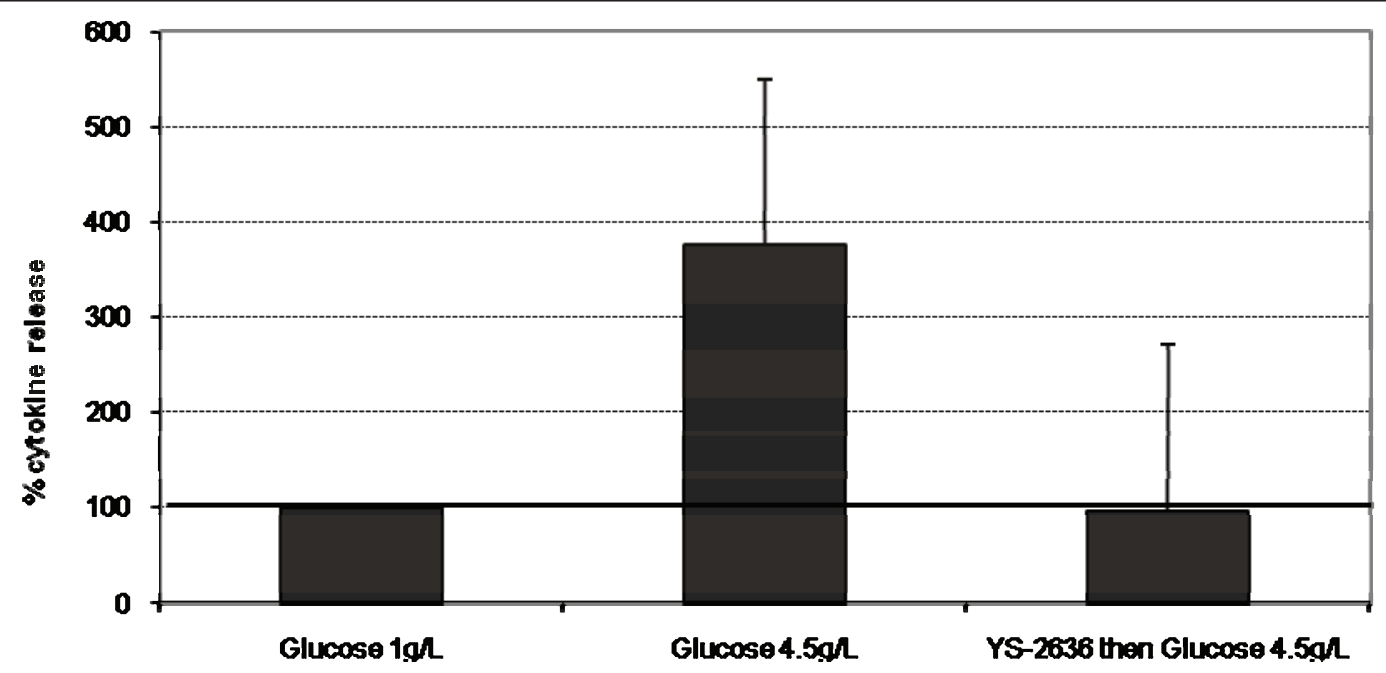

Figure 4 Release of TNF $\alpha$ proinflammatory cytokines. The cells were incubated YS-2636 fish oil for 15 minutes. After the cells were rinsed with phosphate buffer, the cells were incubated with high glucose $(4.5 \mathrm{~g} / \mathrm{L})$ for 48 hours. Normal glucose $(1 \mathrm{~g} / \mathrm{L})$ was used as a cell control. 
Table 2 Effect of fish oil incubation on the fatty acid composition (\%) of RPE cells

\begin{tabular}{ccc}
\hline & Control cells & Cells incubated with YS-2636 oil \\
\hline 20:4w6 AA & 11.60 & $6.65(p<0.001)$ \\
20:5w3 EPA & 1.58 & $4.10(p<0.001)$ \\
22:6w3 DHA & 5.32 & 5.40 \\
\hline PUFA & 29.77 & $39.41(p<0.001)$ \\
PUFA w6 & 20.24 & $26.27(p<0.005)$ \\
PUFA w3 & 9.54 & $13.14(p<0.005)$ \\
\hline
\end{tabular}

AA: arachidonic acid

EPA: eicosapentenoic acid

DHA: docosahexaenoic acid

PUFA: polyunsaturated fatty acid

arachidonic acid in RPE cell membranes, total omega-3 polyunsaturated fatty acids being increased from $9.54 \%$ to $13.14 \%$. When the RPE is under a state of oxidative stress, a molecule called Neuroprotectin D-1 is synthesized by the RPE. Neuroprotectin D-1 is derived from DHA, and provides anti-inflammatory and cellular protection to the retina. This DHA derived molecule protects the retinal cells from damage and consequently cellular death $[23,24]$. Resolvin E1 is derived from EPA and is another omega-3-derived counterregulatory antiinflammatory lipid mediator [25]. EPA and DHA, both precursors of anti-inflammatory lipid mediators, are potent anti-inflammatory agents.

A recent study concluded that fish oil, containing EPA and DHA, improved glucose transporter expressions decreased by insulin [26]. Homeostasis of glucose by insulin involves stimulation of glucose uptake by translocation of glucose transporter from intracellular pool to the caveolar membrane system [27]. In view of the fact

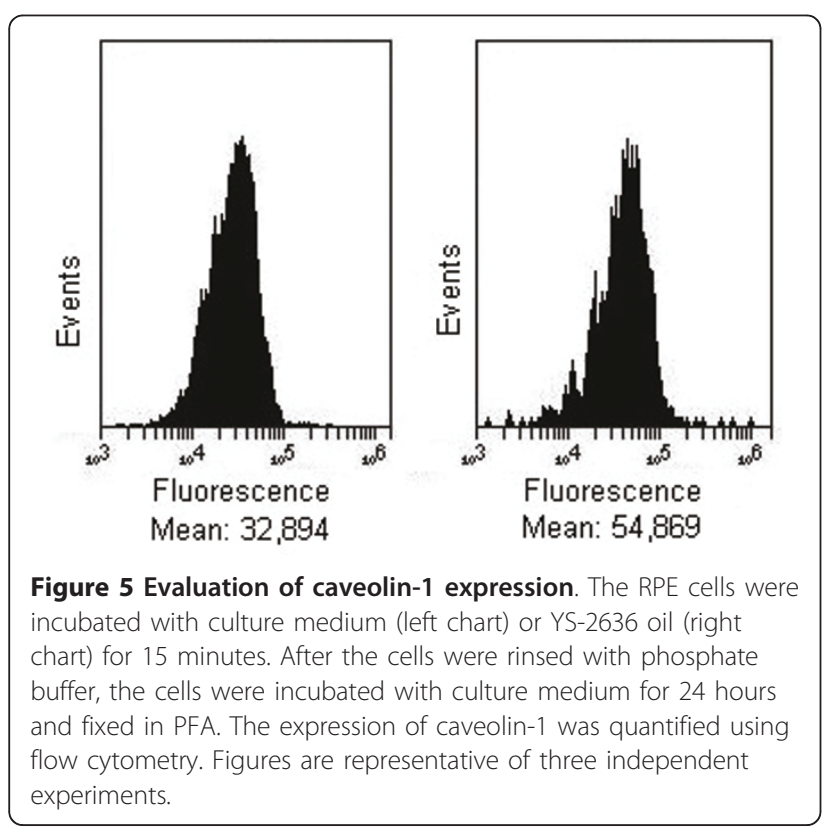

that omega-3-rich oils are able to modulate glucose transporter expression and that glucose transporter translocation is linked to caveolar membrane system, we studied the expression of caveolin-1, an indispensable protein for both the structure and function of caveolae, after incubation of retinal cells with omega-3-rich oil. We observed that the marine omega-3-rich oil we tested increased caveolin-1 expression in RPE cells. Caveolins can promote signaling via enhanced receptor-effector coupling or enhanced receptor affinity when caveolins are up-regulated or overexpressed [28]. Marine omega3-rich oils can up-regulate caveolin-1 expression leading to glucose transporters overexpression in caveolae. Further studies are needed to better understand the underlying mechanisms.

In conclusion, marine EPA and DHA seem beneficial and essential in the modulation of high glucose toxicity for RPE cells. In vivo studies are needed to confirm the therapeutic effects of this oil.

\section{Acknowledgements}

Authors would like to thank Adebiopharm ER67 (financial support).

\section{Author details}

${ }^{1}$ Yslab, Quimper, France. ${ }^{2}$ Laboratoire de Chimie et Toxicologie Analytique et Cellulaire, Faculté de Pharmacie, Université Paris Descartes, Paris, France.

\section{Authors' contributions}

VT carried out the ELISA studies and participated in the design of the study. PR and RF participated in the design of the study and participated in its coordination. All authors read and approved the final manuscript.

\section{Competing interests}

The authors declare that they have no competing interests.

Received: 11 April 2011 Accepted: 16 June 2011

Published: 16 June 2011

\section{References}

1. World Health Organization: Causes of blindness and visual impairment. Diabetic retinopathy, Accessed March, 2010.

2. Engerman RL, Kern TS: Hyperglycemia as a cause of diabetic retinopathy. Metabolism 1986, 35:20-23.

3. Fong DS, Aiello L, Gardner TW, King GL, Blankenship G, Cavallerano JD, Ferris FL, Klein R: Diabetic retinopathy. Diabetes Care 2003, 26:226-229.

4. Madsen-Bouterse SA, Kowluru RA: Oxidative stress and diabetic retinopathy: pathophysiological mechanisms and treatment perspectives. Rev Endocr Metab Disord 2008, 9:315-327.

5. Kowluru RA, Koppolu P, Chakrabarti S, Chen S: Diabetes-induced activation of nuclear transcriptional factor in the retina, and its inhibition by antioxidants. Free Radic Res 2003, 37:1169-1180.

6. Guha M, Bai W, Nadler JL, Natarajan R: Molecular mechanisms of tumor necrosis factor alpha gene expression in monocytic cells via hyperglycemia-induced oxidant stress-dependent and -independent pathways. J Biol Chem 2000, 275:17728-17739.

7. Miyamoto K, Khosrof S, Bursell SE, Rohan R, Murata T, Clermont AC, Aiello LP, Ogura Y, Adamis AP: Prevention of leukostasis and vascular leakage in streptozotocin-induced diabetic retinopathy via intercellular adhesion molecule-1 inhibition. Proc Natl Acad Sci USA 1999, 96:10836-10841

8. Tadayoni R, Paques M, Gaudric A, Vicaut E: Erythrocyte and leukocyte dynamics in the retinal capillaries of diabetic mice. Exp Eye Res 2003, 77:497-504. 
9. Joussen AM, Poulaki V, Le ML, Koizumi K, Esser C, Janicki H, Schraermeyer U, Kociok N, Fauser S, Kirchhof B, Kern TS, Adamis AP: A central role for inflammation in the pathogenesis of diabetic retinopathy. Faseb J 2004, 18:1450-1452.

10. Schnebelen C, Viau S, Gregoire S, Joffre C, Creuzot-Garcher CP, Bron AM, Bretillon L, Acar N: Nutrition for the eye: different susceptibility of the retina and the lacrimal gland to dietary omega- 6 and omega-3 polyunsaturated fatty acid incorporation. Ophthalmic Res 2009, 41:216-224.

11. Schnebelen C, Gregoire S, Pasquis B, Joffre C, Creuzot-Garcher CP, Bron AM, Bretillon L, Acar N: Dietary n-3 and n-6 PUFA enhance DHA incorporation in retinal phospholipids without affecting PGE(1) and PGE (2) levels. Lipids 2009, 44:465-470.

12. Dutot M, Liang H, Martin C, Rousseau D, Grynberg A, Warnet JM, Rat P: Per os administered refined olive oil and marine PUFA-rich oils reach the cornea: possible role on oxidative stress through caveolin-1 modulation. Nutr Metab (Lond) 2009, 6:48.

13. Said T, Dutot M, Christon R, Beaudeux JL, Martin C, Warnet JM, Rat P: Benefits and side effects of different vegetable oil vectors on apoptosis, oxidative stress, and P2X7 cell death receptor activation. Invest Ophthalmol Vis Sci 2007, 48:5000-5006.

14. Said T, Dutot M, Martin C, Beaudeux JL, Boucher C, Enee E, Baudouin C, Warnet JM, Rat P: Cytoprotective effect against UV-induced DNA damage and oxidative stress: role of new biological UV filter. Eur J Pharm Sci 2007, 30:203-210.

15. Linard A, Macaire J, Christon R: Phospholipid hydroperoxide glutathione peroxidase activity and vitamin E level in the liver microsomal membrane: effects of age and dietary alpha-linolenic acid deficiency. J Nutr Biochem 2001, 12:481-491.

16. Yuan Z, Feng W, Hong J, Zheng Q, Shuai J, Ge Y: p38MAPK and ERK promote nitric oxide production in cultured human retinal pigmented epithelial cells induced by high concentration glucose. Nitric Oxide 2009, 20:9-15.

17. Du Y, Miller CM, Kern TS: Hyperglycemia increases mitochondrial superoxide in retina and retinal cells. Free Radic Biol Med 2003, 35:1491-1499.

18. Turrens JF: Superoxide production by the mitochondrial respiratory chain. Biosci Rep 1997, 17:3-8.

19. Ott M, Gogvadze V, Orrenius S, Zhivotovsky B: Mitochondria, oxidative stress and cell death. Apoptosis 2007, 12:913-922.

20. Kashihara N, Haruna Y, Kondeti VK, Kanwar YS: Oxidative stress in diabetic nephropathy. Curr Med Chem 2010, 17:4256-4269.

21. Kern PA, Ranganathan S, Li C, Wood L, Ranganathan G: Adipose tissue tumor necrosis factor and interleukin- 6 expression in human obesity and insulin resistance. Am J Physiol Endocrinol Metab 2001, 280:E745-751.

22. Krogh-Madsen R, Plomgaard P, Keller P, Keller C, Pedersen BK: Insulin stimulates interleukin- 6 and tumor necrosis factor-alpha gene expression in human subcutaneous adipose tissue. Am J Physiol Endocrinol Metab 2004, 286:E234-238.

23. Bazan NG: Cell survival matters: docosahexaenoic acid signaling, neuroprotection and photoreceptors. Trends Neurosci 2006, 29:263-271.

24. Bazan NG: Neurotrophins induce neuroprotective signaling in the retinal pigment epithelial cell by activating the synthesis of the antiinflammatory and anti-apoptotic neuroprotectin D1. Adv Exp Med Biol 2008, 613:39-44.

25. Arita M, Yoshida M, Hong S, Tjonahen E, Glickman JN, Petasis NA, Blumberg RS, Serhan CN: Resolvin E1, an endogenous lipid mediator derived from omega-3 eicosapentaenoic acid, protects against 2,4,6trinitrobenzene sulfonic acid-induced colitis. Proc Natl Acad Sci USA 2005, 102:7671-7676.

26. Nascimento FA, Barbosa-da-Silva S, Fernandes-Santos C, Mandarim-deLacerda CA, Aguila MB: Adipose tissue, liver and pancreas structural alterations in C57BL/6 mice fed high-fat-high-sucrose diet supplemented with fish oil (n-3 fatty acid rich oil). Exp Toxicol Pathol 2010, 62:17-25.

27. Penumathsa SV, Thirunavukkarasu M, Zhan L, Maulik G, Menon VP, Bagchi D, Maulik N: Resveratrol enhances GLUT-4 translocation to the caveolar lipid raft fractions through AMPK/Akt/eNOS signalling pathway in diabetic myocardium. J Cell Mol Med 2008, 12:2350-2361.

28. Raikar LS, Vallejo J, Lloyd PG, Hardin CD: Overexpression of caveolin-1 results in increased plasma membrane targeting of glycolytic enzymes: the structural basis for a membrane associated metabolic compartment. J Cell Biochem 2006, 98:861-871.

doi:10.1186/1743-7075-8-39

Cite this article as: Dutot et al:: New approach to modulate retinal cellular toxic effects of high glucose using marine epa and dha. Nutrition \& Metabolism 2011 8:39.

\section{Submit your next manuscript to BioMed Central and take full advantage of:}

- Convenient online submission

- Thorough peer review

- No space constraints or color figure charges

- Immediate publication on acceptance

- Inclusion in PubMed, CAS, Scopus and Google Scholar

- Research which is freely available for redistribution

Submit your manuscript at www.biomedcentral.com/submit
Biomed Central 